\title{
Requirement for Meaningful Engagement of First Nations, Inuit, Métis, and Indigenous Peoples in Publications About Them
}

\section{Exigence de participation concrète des Premières nations, des Inuits, des Métis et des peuples autochtones aux publications à leur sujet}

\author{
Janet Smylie ${ }^{1,2,3} \cdot$ Namaste Marsden $^{4,5} \cdot$ Leona Star $^{6}$ - Jacqueline Gahagan ${ }^{7}$. Christina Zarowsky ${ }^{8,9,10}$. \\ Eric Mykhalovskiy ${ }^{11,12} \cdot$ Jeff Masuda ${ }^{13,14} \cdot$ Louise Potvin $^{15,16}$
}

Published online: 7 December 2020

(C) The Canadian Public Health Association 2020

There is wide recognition that First Nations, Inuit, Métis (FNIM) and Indigenous Peoples face historic and ongoing injustices, including the exclusion, marginalization, and/or misrepresentation of their voices and perspectives in academic publications about them. In Indigenous health and public health scholarship, a persistent deficit-based focus on risk, disease, and social problems presents a missed opportunity to learn from and advance the diversity of strength-based FNIM and Indigenous health and well-being models and practices. The inherent rights of Indigenous Peoples to selfdetermine their economic, social, cultural and knowledge development are recognized in domestic and international law and ethics. This includes the right to be meaningfully engaged in scholarship concerning them, which is often relied upon as evidence for decision-making. In an effort to enhance the social value and utility of our publication, and improve alignment with domestic and international law and ethics - the TriCouncil Policy Statement on Ethical Conduct for Research Involving Humans (TCPS; Government of Canada 2018), the Calls to Action of the Truth and Reconciliation Commission (TRC) of Canada (Government of Canada 2015), and the United Nations Declaration on the Rights of Indigenous Peoples (UNDRIP 2007) - the Canadian Journal of Public Health (CJPH) requires that all
Janet Smylie

janet.smylie@utoronto.ca

CJPH Senior Editor, Toronto, ON, Canada

2 Tier 1 Canada Research Chair in Generative Health Services for Indigenous Populations in Canada and Director of Well Living House, St. Michael's Hospital, Toronto, ON, Canada

3 Dalla Lana School of Public Health, University of Toronto, Toronto, ON, Canada

4 First Nations Health Authority, West Vancouver, BC, Canada

5 Faculty of Health Sciences, Simon Fraser University, Burnaby, BC, Canada

6 First Nations Health and Social Secretariat of Manitoba, Winnipeg, MB, Canada

7 Dalhousie University, Halifax, NS, Canada
C CJPH Senior Editor, Montreal, QC, Canada

Département de médicine sociale et préventive, École de Santé Publique, Université de Montréal, Montreal, QC, Canada

10 School of Public Health, University of the Western Cape, Cape Town, South Africa

11 CJPH Senior Editor, Toronto, ON, Canada

12 Department of Sociology, York University, Toronto, ON, Canada

13 CJPH Senior Editor, Kingston, ON, Canada

14 Canada Research Chair in Environmental Health Equity, School of Kinesiology and Health Studies, Queen's University, Kingston, ON, Canada

15 CJPH Editor-in-Chief, Montreal, QC, Canada

16 School of Public Health, University of Montreal, Montreal, QC, Canada 
authors answer the following questions as part of the manuscript submission process:

1. Are First Nations, Inuit, Métis, and/or Indigenous Peoples or populations a focus of this submission? Yes/No

2. If yes, were the relevant Indigenous Peoples or populations engaged in the study and/or preparation of this submission? Yes/No

3. If yes, please summarize how the relevant Indigenous Peoples or populations have been engaged as individuals and collectively in the study and/or preparation of this submission (2000 character limit).

Manuscripts that are identified by the submitting author or deemed by the Editor-in-Chief, or Senior/Associate Editors -Indigenous, to have a focus on First Nations, Inuit, Métis, and/or Indigenous Peoples or populations (Appendix B) that do not include additional information about FNIM and/or Indigenous community engagement will be considered incomplete.

Complete manuscripts that meet the inclusion criteria will be screened to ensure they meet editorial standards for Indigenous community engagement (Appendix C) by Senior and Associate Editors-Indigenous with support of the Editorin-Chief. Manuscripts that do not meet editorial standards will be declined. Manuscripts that do meet or exceed editorial standards will be sent out for peer review.

The CJPH is committed to appointing Senior and Associate Editors who will be self-identified Indigenous public health scholars, who are university and/or community-based, and who are recognized by both First Nations, Inuit, Métis communities and public health peers. The CJPH is further committed to developing and sustaining a network of Indigenous and allied expert multidisciplinary Indigenous health and public health peer reviewers who are knowledgeable regarding the standards for Indigenous community engagement in research, experienced in their application, and committed to their advancement. Indigenous peer reviewers will additionally be required to have knowledge of Indigenous health research ethics, principles and processes. Indigenous peer reviewers will include academics, health and public health practitioners, and Indigenous community and organizational representatives. All peer reviewers will receive a copy of the CJPH editorial standards for Indigenous community engagement (Appendix C).

\section{Appendix A - Key Terms}

The term Indigenous is used to recognize the many globally diverse nations of peoples who share continuities of kin-lines and land-ties pre-dating colonization and the rights inherent to this legacy. The terms First Nations, Inuit, and Métis recognize and assert the unique rights, interests and circumstances of these distinction-based groups, who are Indigenous to the lands now known as Canada. The term Aboriginal is a federal term collectively referring to all of the Indigenous Peoples of Canada and their descendants. The Canadian Constitution Act of 1982 (Government of Canada n.d.a) specifies that the Aboriginal Peoples in Canada consist of three groups: Indians, Inuit and Métis. The terms Aboriginal and Indian may be used when referencing this legislation and texts applying this terminology, noting that externally imposed Constitution (Government of Canada n.d.-a) and Indian Act (Government of Canada n.d.-b) definitions of Indigeneity are not well aligned with the diverse and self-determined ways in which Indigenous Peoples identify themselves, their kin-lines, their territories, and nations.

Indigenous Community Research Engagement is a process that establishes interaction between a researcher and/or research team and the Indigenous community relevant to the research project and/or scholarly publication. Recognizing that this can take many forms, we have identified some minimal standards for Indigenous community engagement in scholarly publications (Appendix C).

\section{Appendix B - Inclusion Criteria}

Manuscripts will be considered to have an Indigenous focus when they:

1. Describe primary data collection or analysis involving First Nations, Inuit, Métis, and/or Indigenous Peoples or populations. This includes studies with FNIM and/or Indigenous subsamples and/or subanalyses.

2. Involve secondary data analysis, including but not limited to systematic reviews and analyses of existing databases, that includes Indigenous-specific results or study sample(s) for which a significant proportion of participants are known to be Indigenous.

3. Are commentary, policy or practice submissions with an Indigenous focus.

This editorial policy will focus on FNIM and/or Indigenous populations living in what is now called Canada. At the discretion of the Editor-in-Chief and Editors-Indigenous, manuscripts focused on international Indigenous populations may be referred to international Indigenous journals. 


\section{Appendix C - Editorial Standards}

Submissions that include a focus on First Nations, Inuit, Métis, and/or Indigenous Peoples must demonstrate as a minimum threshold standard evidence that:

Relevant community leaders and/or representatives from the First Nations, Inuit, Métis, and/or Indigenous populations whose information is being shared or analyzed and/or about whom statements are being made have been i) contacted; ii) made aware of the manuscript; and iii) engaged in the production of the manuscript and linked scholarly activities in a way that reflects their protocols and priorities and ensures the inclusion of Indigenous voice.

Examples of evidence that these minimal threshold standards are being met could include:

- Formalized research, data-governance, and/or publication agreements between academic authors and community leaders and/or representatives from First Nations, Inuit, Métis, and/or Indigenous populations whose information is being shared or analyzed and/or about whom statements are being made.

- Inclusion of relevant FNIM and/or Indigenous community leaders and/or representatives as co-authors on the manuscript.

We note that these are minimal threshold standards. Benchmark approaches to Indigenous scholarship, including scholarly writing, involve:

- Leadership of all activities by community leaders and/or representatives from First Nations, Inuit, Métis, and/or Indigenous populations whose information is being shared or analyzed and/or about whom statements are being made.

- Meaningful engagement of community leaders and/or representatives from First Nations, Inuit, Métis, and/ or Indigenous populations whose information is being shared or analyzed and/or about whom statements are being made at the pre-conception stage of the project to ensure that the scholarly work reflects the priorities, aspirations, needs, and worldview of the First Nations, Inuit, Métis, and/or Indigenous populations whose information is being shared or analyzed and/or about whom statements are being made.

- Indigenous methodologies and integrated models of knowledge translation appropriate to the population of focus.
Exigence de participation concrète des Premières nations, des Inuits, des Métis et des peuples autochtones aux publications à leur sujet

Il est largement reconnu que les Premières Nations, les Inuits et les Métis (PNIM) et les peuples autochtones sont victimes d'injustices historiques et actuelles, dont l'exclusion, la marginalisation et/ou la représentation trompeuse de leurs voix et de leurs points de vue dans les publications scientifiques à leur sujet. Dans les travaux d'érudition sur la santé et la santé publique autochtones, l'accent constamment mis sur les lacunes (les risques, les maladies et les problèmes sociaux) représente une occasion manquée d'apprendre des modèles et des pratiques de santé et de bien-être des PNIM et des peuples autochtones, fondés sur les forces, et d'en faire progresser la diversité. Les droits inhérents des peuples autochtones à déterminer leur propre développement en matière économique, sociale, culturelle et de connaissances sont reconnus dans le droit et l'éthique canadiens et internationaux. Cela comprend leur droit de participer concrètement aux travaux d'érudition qui les concernent, qui servent souvent de preuves dans la prise de décisions. Afin de rehausser la valeur sociale et l'utilité de notre publication et de la rendre plus conforme au droit et à l'éthique canadiens et internationauxà l'Énoncé de politique des trois Conseils sur l'Éthique de la recherche avec des êtres humains (EPTC) (Government of Canada 2018), aux Appels à l'action de la Commission de vérité et réconciliation (CVR) du Canada (Government of Canada 2015), et à la Déclaration des Nations Unies sur les droits des peuples autochtones (DNUDPA) (UNDRIP 2007)—la Revue canadienne de santé publique (RCSP) demande que les auteurs répondent aux questions suivantes lorsqu'ils soumettent des manuscrits :

1. Cette soumission concerne-t-elle les Premières Nations, les Inuits, les Métis et/ou les peuples ou les populations autochtones?

Oui/Non

2. Si oui, les peuples ou les populations autochtones concernés ont-ils participé à l'étude et/ou à la préparation de cette soumission?

Oui/Non

3. Si oui, veuillez expliquer brièvement (en 2000 caractères ou moins) comment les peuples ou les populations autochtones concernés ont participé individuellement et collectivement à l'étude et/ou à la préparation de cette soumission.

Les manuscrits qui concernent les Premières Nations, les Inuits, les Métis et/ou les peuples ou les populations autochtones (annexe B) selon l'auteur présentateur ou selon la rédactrice en chef/le rédacteur en chef ou les rédacteurs 
scientifiques adjoints/associés autochtones et qui ne contiennent pas d'informations supplémentaires sur la participation des PNIM et/ou des communautés autochtones seront jugés incomplets.

Les manuscrits complets qui respectent les critères d'inclusion seront passés au crible par les rédacteurs scientifiques adjoints/associés-autochtones, avec l'appui de la rédactrice en chef/du rédacteur en chef, pour voir s'ils respectent les normes éditoriales de participation des communautés autochtones (annexe C). Les manuscrits qui ne respectent pas les normes éditoriales seront refusés. Les manuscrits qui respectent ou dépassent les normes éditoriales seront envoyés pour évaluation par les pairs.

La RCSP s'engage à nommer des rédacteurs scientifiques adjoints/associés qui s'auto-identifient comme étant des théoriciens de la santé publique autochtones en milieu universitaire et/ou en milieu ouvert et qui sont reconnus à la fois par les communautés métisses, inuites ou des Premières Nations et par leurs pairs de la santé publique. La RCSP s'engage aussi à créer un réseau pluridisciplinaire d'évaluateurs de textes autochtones et de spécialistes alliés en santé et en santé publique autochtones et à assurer la continuité de ce réseau; les évaluateurs devront connaître les normes en matière de participation communautaire autochtone à la recherche, posséder de l'expérience dans l'application de ces normes et s'engager à les faire progresser. Les évaluateurs autochtones seront aussi tenus de connaître l'éthique, les principes et les processus de recherche en santé autochtone. Les évaluateurs autochtones incluront des théoriciens, des praticiens de la santé et de la santé publique et des représentants de communautés et d'organisations autochtones. Tous et toutes recevront une copie des normes éditoriales de la RCSP sur la participation des communautés autochtones (annexe C).

\section{Annexe A - Termes clés}

Le mot indigène est employé pour reconnaître dans toute leur diversité les nombreuses nations de peuples dans le monde qui ont en commun des liens parentaux et territoriaux datant d'avant la colonisation et des droits inhérents à ce patrimoine. Les termes Premières Nations, Inuits et Métis reconnaissent et affirment les droits, les intérêts et les circonstances uniques des groupes distincts qui sont indigènes aux territoires qu'on appelle aujourd'hui le Canada. Le nom Autochtones est un terme du gouvernement fédéral qui désigne collectivement les peuples autochtones du Canada et leurs descendants. La Loi constitutionnelle canadienne de 1982 (Government of Canada n.d.-a) précise que l'expression « peuples autochtones du Canada » s'entend de trois groupes : les Indiens, les Inuits et les Métis. Le mot Indien(ne) peut être utilisé lorsqu'on cite cette loi et les textes qui appliquent cette terminologie, mais on notera que les définitions de l'indigénéité imposées de l'extérieur qui figurent dans la Constitution (Government of Canada n.d.-a) et dans la Loi sur les Indiens (Government of Canada n.d.-b) cadrent mal avec les diverses façons dont les peuples autochtones s'auto-identifient et identifient leurs liens parentaux, leurs territoires et leurs nations.

La participation des communautés autochtones à la recherche est un processus qui établit l'interaction entre un chercheur/une chercheuse et/ou une équipe de recherche et la communauté autochtone concernée par le projet de recherche et/ou par une publication scientifique. Sachant que cette interaction peut prendre de nombreuses formes, nous avons défini des normes minimales de participation des communautés autochtones aux publications scientifiques (annexe C).

\section{Annexe B - Critères d'inclusion}

Les manuscrits seront considérés comme concernant les peuples autochtones lorsqu'ils :

1. Décrivent la collecte ou l'analyse de données primaires impliquant les Premières Nations, les Inuits, les Métis et/ ou des peuples ou des populations autochtones. Cela comprend les études ayant des sous-échantillons ou des sous-analyses ciblant les PNIM et/ou les peuples autochtones.

2. Impliquent l'analyse de données secondaires, par exemple des revues systématiques et des analyses de bases de données existantes, incluant des résultats ou des échantillons d'études spécifiques aux peuples autochtones et dont on sait qu'une proportion importante de participants est autochtone.

3. Sont des commentaires, des politiques ou des pratiques portant sur les peuples autochtones.

Cette politique éditoriale sera axée sur les PNIM et/ou les populations autochtones qui habitent ce qu'on appelle aujourd'hui le Canada. À la discrétion de la rédactrice en chef/du rédacteur en chef et des rédacteurs-autochtones, les manuscrits portant sur les populations indigènes à l'étranger pourront être adressés à des revues indigènes internationales.

\section{Annexe C - Normes éditoriales}

Les soumissions qui traitent des Premières Nations, des Inuits, des Métis et/ou des peuples autochtones doivent minimalement démontrer que :

Les dirigeants locaux et/ou les représentants des Premières Nations, des Inuits, des Métis et/ou des populations autochtones dont les informations sont 
communiquées ou analysées et/ou à propos desquels des déclarations sont faites ont été : i) contactés; ii) informés du manuscrit; et iii) impliqués dans la production du manuscrit et des activités scientifiques connexes d'une façon qui reflète leurs protocoles et leurs priorités et qui assure l'inclusion de la voix autochtone.

Voici des exemples possibles de preuves que ces normes minimales ont été respectées :

- Des ententes officielles de recherche, de gouvernance des données et/ou de publication conclues entre les auteurs théoriciens et les dirigeants locaux et/ou les représentants des Premières Nations, des Inuits, des Métis et/ou des populations autochtones dont les informations sont communiquées ou analysées et/ou à propos desquels des déclarations sont faites.

- L'inclusion des dirigeants locaux et/ou des représentants des PNIM et/ou des populations autochtones concernés parmi les coauteurs du manuscrit.

Notons que ce sont là des normes minimales. Des démarches optimales à l'égard des travaux d'érudition autochtones, y compris la rédaction scientifique, impliquent :

- La direction de toutes les activités par les dirigeants locaux et/ou les représentants des Premières Nations, des Inuits, des Métis et/ou des populations autochtones dont les informations sont communiquées ou analysées et/ou à propos desquels des déclarations sont faites.

- La participation concrète des dirigeants locaux et/ou des représentants des Premières Nations, des Inuits, des Métis et/ou des populations autochtones dont les informations sont communiquées ou analysées et/ou à propos desquels des déclarations sont faites à l'étape de préconception du projet pour que le travail d'érudition reflète les priorités, les aspirations, les besoins et la vision du monde des Premières Nations, des Inuits, des Métis et/ou des populations autochtones dont les informations sont communiquées ou analysées et/ou à propos desquels des déclarations sont faites.

- Des méthodes autochtones et des modèles intégrés d'application des connaissances adaptés à la population ciblée.

Acknowledgements The authors would like to acknowledge the Forum for Indigenous Implementation Research and Evaluation (FIIRE) and the full Editorial Board of the CJPH for their support and assistance with this policy. / Les auteures et auteurs reconnaissent le Forum for Indigenous Implementation Research and Evaluation (FIIRE) ainsi que la Comité de rédaction de la RCSP pour leur soutien et leur aide avec cette politique.

\section{References/Références bibliographiques}

Government of Canada. (n.d.-a). Canadian Constitution Act of 1982. https://laws-lois.justice.gc.ca/eng/const/page-15.html\#h-38. Accessed 4 Oct 2020.

Government of Canada. (n.d.-b). Indian Act. https://aws.justice.gc.ca/ eng/acts/I-5/. Accessed 4 Oct 2020.

Government of Canada. (2018). Canadian Institutes of Health Research, Natural Sciences and Engineering Research Council of Canada, and Social Sciences and Humanities Research Council, Tri-Council Policy Statement: Ethical Conduct for Research Involving Humans, December 2018. https://ethics.gc.ca/eng/policypolitique_tcps2-eptc2_2018.html. Accessed 4 October 2020.

Government of Canada. (2015). Summary Report of the Truth and Reconciliation Commission of Canada. http://nctr.ca/assets/reports/ Final\%20Reports/Executive_Summary_English_Web.pdf. Accessed 26 October 2020.

UNDRIP. (2007). United Nations Declaration on the Rights of Indigenous Peoples. New York, NY. https://www.un.org/ development/desa/indigenouspeoples/declaration-on-the-rights-ofindigenous-peoples.html. Accessed 4 October 2020.

Publisher's note Springer Nature remains neutral with regard to jurisdictional claims in published maps and institutional affiliations. 